\title{
Changes of Some Physico-Mechanical Parameters of Vascular Patches After Subcutaneous Implantation
}

\author{
Severinov Dmitry Andreevich ${ }^{1 *}$, Naimzada David Mahomed Ziyautdin ${ }^{2}$ and Lipatov Vyacheslav \\ Aleksandrovich ${ }^{3}$ \\ ${ }^{1}$ Student of the $6^{\text {th }}$ course of Pediatric faculty, Russian Federation \\ ${ }^{2}$ Clinical intern of department of Surgical diseases, faculty of post-qualifying education, Russian Federation \\ ${ }^{3}$ Doctor of medical sciences, professor of department of operative surgery and topographic anatomy, Russia \\ *Corresponding author: Severinov Dmitry Andreevich, Student of the $6^{\text {th }}$ course of pediatric faculty, Russian Federation
}

\section{ARTICLE INFO}

Received: 慧 September 15, 2019

Published: 慧 September 23, 2019

Citation: Severinov Dmitry A, Naimzada David M Z, Lipatov Vyacheslav A. Changes of Some Physico-Mechanical Parameters of Vascular Patches After Subcutaneous Implantation. Biomed J Sci \& Tech Res 21(3)-2019. BJSTR. MS.ID.003613.

Keywords: Implant; Physio Mechanical Properties; Connective Tissue; Implantation; Strength

\begin{abstract}
Modern medical progress characterized by quantitative growth of medical equipment and devices presented on the market. Studies of recipient tissue reactions to implantation of new types of implants seems relevant. Meanwhile, mechanical and physical characteristics of materials, usually used for implant manufacturing, described superficially and non-evidentiary. For some sorts of implants, such as cardiovascular, type of used materials and surface characteristics plays one of the fundamental and most important roles. It known that recipient organs and tissues influence the properties of the implant. We aimed to study physical and mechanical characteristics of cardiovascular patches after in vivo implantation under the skin. 60 Vistar rats and 2 types of polyethylene terephthalate cloth with and without gelatin impregnation were used in 15 and 30-days experiment. For measuring, we used RT-250M machine according to the GOST 8847-85 Russian national standard. For gelatin impregnated samples reduced physical strength is shown if compared to non-impregnated samples.
\end{abstract}

\section{Editorial}

Modern medical progress characterized by quantitative growth of medical equipment and devices presented on the market [13]. Russian modernization program including the elaboration on one of most intensive growing public health domains surgery [4,5]. Surgical implant is organic or syn-thetic material used for: substitution of specific body functions for a long time, patching of tissue defects, or strengthening of native body tissues $[4,6,7]$. High functionality of surgical implants determined by such characteristics as elasticity, durability, tensile strength [1]. Depending of the purpose of the surgical implant, different set of characteristics, listed above, is required for better performance and reliability [8]. We aimed to define physical and mechanical characteristics of different tissue samples in vivo, used to make cardiovascular patches. Tensile strength and percent elongation of various cardiovascular patches samples was measured after implantation under the skin of laboratory animals.
For research was used 2 different samples were used. Both were made of thin layer of polyethylene terephthalate; sample №2 was impregnated in gelatin. The experiment was performed on Vistar rats. 60 animals weighting 200-250 g maintained in vivarium of Kursk State Medical University. Laboratory animals' regulations and recommendations was complied. All animals underwent general anesthesia, skin and subcutaneous fat dissection. The $7 \mathrm{~cm}$ long inclusion performed right from paravertebral line in parallel to spine. Two 3,5 $\mathrm{cm}$ deep pockets were formed between muscular and skin layers left and right from incision. Implant samples $5 \times 1 \mathrm{~cm}$ in size were inserted in each pocket. Incisional wound was sewn using single-knot sutures. Animals were sacrificed after 15 days (30 rats) and 30 days (30 rats) after implantation. All corpses underwent autopsy. Each implant was extracted and peeled from enveloping tissues. Strength properties of samples was measured using RT250M machine according the GOST 8847-85 Russian national 
standard. Results were com-pared using confidence interval with the cutoff of $\mathrm{P} \leq 0.05$ whether potential differences were significant. Best results were obtained from non-impregnated implants, which could resist linear force up to $142 \mathrm{~N}$ (15 days from implantation) and $150 \mathrm{~N}$ (30 days often implantation).

Obtained data showing high tensile strength of cardiovascular patches made from polyethylene terephthalate. Also, we found interesting, that percent elongation was varying from $6 \%$ to $52 \%$ independently from duration of experiment and gelatin impregnation. Minimal tensile strength $(60 \mathrm{~N}$ at 15 and 30 days after experiment start) was observed in samples №2 (gelatins impregnated). Gelatin impregnation, usually used for decreasing surgical porosity of materials, also significantly reduce biological porosity, which in turn make the incorporation process more complex, and longer, and less native, at least, during in vivo experiments. Effects, listed above, results in deceleration of intergrowth with connective scar tissue and decreasing of strength properties in sample №2 comparing to sample №1.

\section{Conclusion}

a) Polyethylene terephthalate patches for cardiovascular use do not deform and not change them physio mechanical properties after implantation under the skin of Vistar rats.

b) Impregnation process result in filling the gaps between polyethylene terephthalate fibers, which in our opinion decrease biological porosity and tensile strength.

ISSN: 2574-1241

DOI: 10.26717/BJSTR.2019.21.003613

Severinov Dmitry Andreevich. Biomed J Sci \& Tech Res

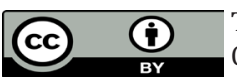

This work is licensed under Creative Commons Attribution 4.0 License

Submission Link: https://biomedres.us/submit-manuscript.php

\section{References}

1. Alukhanyan OA (2012) The comparative characteristic of new samples vascular patches from a politetraftoretilen in an experiment. Angiology and vascular surgery 2: 45-51.

2. PV Tkachenko, VA Lipatov, IL Privalova, DA Severinov, NI Hmaro (2016) Ethic and legal aspects of experimental practice. Online scientific magazine 1(2): 29-35.

3. AV Ivanov, VA Lipatov, SV Lazarenko, NN Zherdev, DA Severinov (2016) Influence of mechanical characteristics vascular patch on formation periprotezny capsule. Clinical and experimental surgery 1: 51-57.

4. Ivanov AV, Lipatov VA, Lazarenko SV, Zherdev NN, Severinov DA (2016) Research of reaction tissues laboratory animals to implantation of new samples vascular endoprosthesis. Pathology circulation and heart surgery 20(2): 87-94.

5. Lipatov VA (2015) Physicomechanical and structural properties of the implants intended for transactions on the main vessels. 11: S92-98.

6. Lipatov VA, Grehneva EV, Mezenceva IV (2015) Assessment of reaction of tissues of laboratory animals to intramuscular introduction of covers of microcapsules on the basis of polymers of alginate of sodium, guar gum, kollidon as carrier of medicinal substances for treatment and prevention of surgical diseases. Verhnevolzhskij medicinskij zhurnal 1: S22-26.

7. Sukovatyh BS (2014) Modern technologies of prevention of a postoperative spaykoobrazovaniye. 173(5): S98-102.

8. DL Salzmann, LB Kleinert, SS Berman, SK Williams (2016) The effects of porosity on endothelialization ePTFE implanted in sub-cutaneous and adipose tissue. J Biomed Mater Res 34: 463-476.

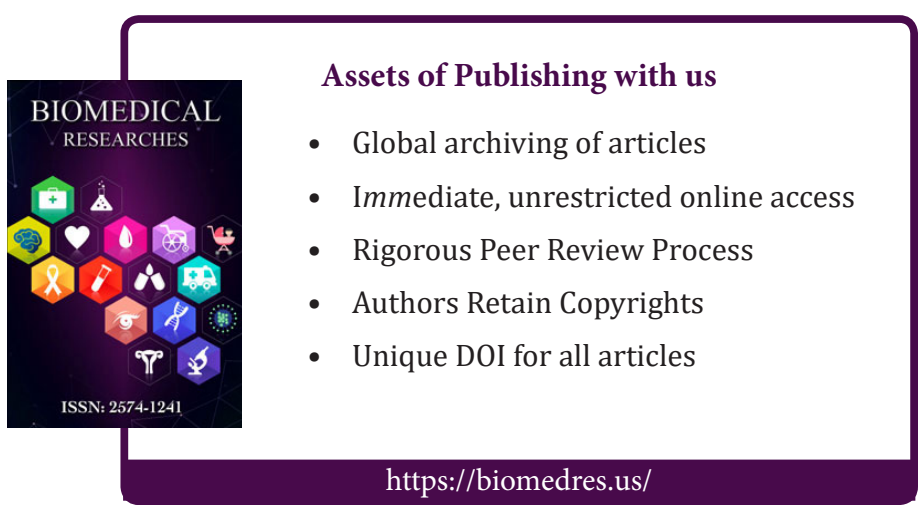

